\section{OP-249 経腹膜的腹望鏡下副朢摘除術の検即}

\begin{abstract}
徳島大学 医学部 泌尿器科" 天理よろづ相談所病院" 高松市民病院31 高松赤十字病院")要媛県立中央病院5) 金山博臣”, 沼田 幸作", 井䗁 博文", 大西 智一郎” 奈路田 拓史",黑川 夷史", 香川 征", 寺地 敏郎" 大森 正志 ${ }^{3)}$,小島 圭二4), 昔 政治5) 【目的】経腹膜的腹腔鏡下副腎摘除術について検討を行った。対象と方法】 1994 年 7 月から 2001 年 11 月の間に徳島大学および関連病院において経 腹膜的腹腔鏡下副腎摘除術を施行した 57 例 (男性 26 湖、女性 31 例、平均 年龄 53 歳)を対象とした。手衍時間、出血量、術中衍後合併症等について検 討を行った。結果]1994·1995年各1例、1996 年3例、1997・1998 年各 4 例、1999年 11 例、2000 年 23 例、2001 年 10 例であった。術前診断は、内分

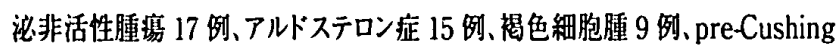
症侯群 6 例、Cushing 症侯群 2 例、副腎癌疑い 2 洌、転移性副腎㿋疑い 2

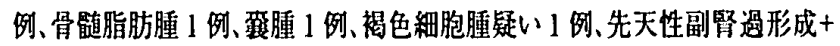
画側骨㩆腫 1 例であった。1 例が開腹術に移行し、残り56 例の検討では、副 腎の摘除は片㑡摘除が 53 例、西㑡摘除が 2 例、部分切除が1例であった。 手術時間は片例例 54 例が $186.0 \pm 50.0$ 分、両国例 2 例では 270 分、275 分

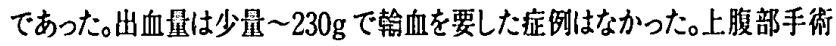
の既往を有する4例も経腹膜的に完遂できた。術中合併症は胸椎圧迫骨折 が1例であった。潰瘍性大腸炎の1 例で術後イレウスとなったが腹腔鏡下剥 離術により治療できた。(結詥)経腹膜的腹腔镜下副腎摘除術は梘野が広くオ リエンテーションが容易であり上腹部手術の既往例にも安全に施行できた。 腹腔鏡下副腎摘除術 経腹膜的
\end{abstract}

\section{OP-250 青少年期の精索静眽瘤手術の検畎}

\section{関西医科大学 泌尿器科}

六車 光英,島田 治, 川端 和史, 佐藤 尚, 整野 祥三 大口 尚基, 日浦 義仁, 藤田一郎, 内田 潤二, 河 源 室田 卓之, 小山 泰樹, 松田 公志

【目的】青少年期の精索静脈痗手術の有用性を検詂した.【方法】 1991 年 12 月〜2001 年 10 月に当科で精索静脈瘤手術を行った 20 歳末渵の 21 例 (对側精栄摘除後, 対側精管閉塞の各 1 例を含む) を後向きに検討した. 年㱓は 10〜14 歳 10 例, 15〜19歳 11 例, 患 側は全例左のみ, Grade は II が 3 例, III が 18 例で，患側の精紧容 皘は健側に比べ有意に小さかった. 15 歳以上の全例で術前に精液 検查を行い，乏精子症または無力精子症を 3 例，無精子症を 1 例 (対側精管閉塞例)に認めた. [結果】1994 年 1 月までの 8 例は腹腔 鏡手術, 1994 年 2 月以降の 13 例は低位結禁術を行った.手術時間 は腹腔镜手術 $89 \pm 17$ 分,低位結禁術 $110 \pm 28$ 分 (n.s.), 術後在院 日数は 1992 年は 9.3 日であったが, 2001 年は 3.7 日と短樎してい

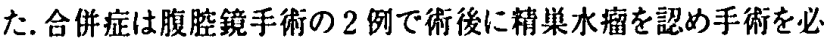

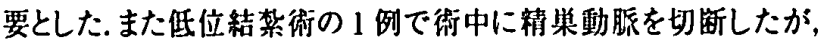

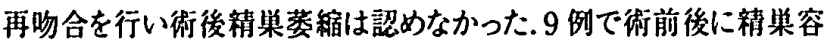

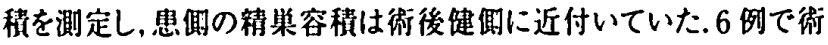
前後に皘液検査を行い，衍前乏皘子症または無力靖子症を認めた 3 例中 2 例は正常となった. [結諭]䄇案静胝疾手街は青少年期にも有 用で，影铔鏡下低位結禁沺は青少年期でも十分可能である。

精索静脈瘤 青少年期 手術

\section{OP-251佇留精巣術後、精巣サイズの变化につい ての梌狽}

\begin{abstract}
北里大学 医学部 泌尿器科" 国立横浜病院 泌尿器 科2) 協和病院3) 埼玉共同病院 泌尿器科(1 埼玉県央病院 ${ }^{51}$

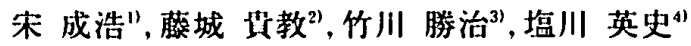
遠藤 忠雄 ${ }^{51}$, 馬場 志郎"

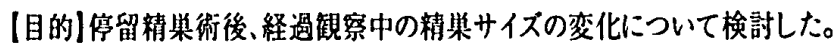
【対象と方法】1998 年 5 月から 2000 年 8 月までの 3 年間に、停留精巣の 診断により外科治療を 67 症例に行った。のうち精栄固定術を行われた患 者は 55 例であった。 40 症例で衍前拉よび、衍後 1 年目、2 年目、3 年目に

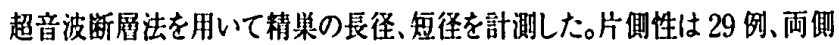
性が11例であった。の 51 精巣にこついての計測値を、健側と思㑡ならびに

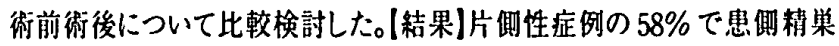
が小さかった。術後 1 年目の計測では、41\%の症例で術後精巣の長径の 增大が認められた。方 $14 \%$ の症例に長径の縮小を認めたが、萎縮した 症例はなかった。煡側精巣は 48\%に精紧長径の增大を諗めていた。両側性 の症例では、長径の縮小が $18 \%$ に詔め、增大が $27 \%$ であった。術後 2 年 目以降では $52 \%$ の症例で長径が増大していたまた 2 嵅以前に手術をし た症例のほうか、精坚サイスの增大が認められる㑯向があった。結語】停留 精巣の手術時期は germ cell countsが 1-2 歳時から急速に增加すること や、自然に降下する可能性が 1 歳以後少なくなると、germ cell のタメージ

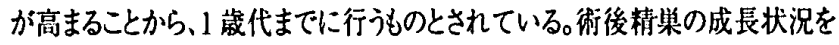
超音波にて経時的に観察をし、臨床的因子との関倸について検討した。 停溜精巣 超音波 精巣サイズ
\end{abstract}

\section{OP-252 性分化異常に対する小児泌尿器科的治䙲 と成精}

\section{都立清瀬小児病院 泌尿器科}

中井秀郎, 浅沼 宏, 佐藤 裕之, 森 義明, 穴戸 清一郎

目的)性分化異常小児に対する垠近の手術的治療成績と問题 点を明らかにする。对象) 乳幼児期に治療した社会的男児 20 例、女览 19 例。混合性性腺異形成 7 例、先天性副腎皮犋過形 成 8 例、真性半陰陽 7 例、アンドロゲン不応症 6 例、その疑 2 例、原発性精单低形成 8 例、精坚退縮症候群 1 例。方法)男児 例で 7 性腺を摘出、18 精紧を固定。女览例で 22 性腺を摘出。16 例に一期的尿道下裂根治術(平均 1 嵅 10 ヶ月、尿道長 49 $\mathrm{mm}) 、 2$ 例に陰蒜形成術、3 例に経膀胱的搪大前立腺小室摘 出。12 例に女坚外㓌凌形成術 (平均 2 歳 4 ヶ月) (flap 法 9 例、 pull-through 法 3 例)、5例(アンドロゲン不応症と棈柴退樎症候 群)に女児外陰形成術(平均 1 歳 6 个月)。結果)尿道下裂 16 例 中 5 例に再手術。離開尿道形成、挍孔切除、外尿道口形成が行 われ現在は機能的形態的に满足できる状態。女性化手術 1 例で 尿道堙接。全形成䐦口に経血排出困難が予想される狭窄なし。 造凌術待機 5 例は思春期前の手術予定。考察)充分なサイズの 㓌茎が期待できれば、下裂重症度によらず男性化手術の成紿满 足度は溌能的形態的に高い。女性化手街は腔が高位で小さいと 困䨀だが、衍式の工夫により满足度の追求可能。唯ーアンドロゲ ン不店症での高度陰茎発育不全では女性化手術以外の選択枝 がなく術式も造䐦術に限られるため、機能的满足度は低い。 性分化異常 乳幼児 手術 